\title{
Problems of Voting Rights in Elections in Siak Regency, Riau Province
}

\begin{abstract}
Elections are a means of democracy used to rotate governmental circles, both executive and legislative powers. Voter participation in the holding of elections in 2019 is very high compared to the previous elections and therefore the potential for voters who cannot use their voting rights is very high as well. The research method used is sociological juridical research methods, with data collection techniques from primary data sources, data collection techniques by interviewing, observing, and studying literature. Problems in the form of the exercise of voting rights in Siak Regency in the General Election, that every voter can use their voting rights at the polling station, but in the implementation of simultaneous elections in 2019 in Siak District there are still Voters who cannot give their voting rights due to the endless availability of ballots, this is due to lack of effective in carrying out the data collection of potential voters conducted by election organizers when updating data, systems and infrastructure and the readiness of organizers to face simultaneous elections, low public awareness of their own voting rights.
\end{abstract}

Keywords: Election; Voters; Voting Rights

\section{Introduction}

Elections are in essence a system of netting public officials that are widely used by countries in the world with a democratic government system, for a number of countries that implement or claim to be democratic (popular sovereignty), elections are one of the conditions for democracy, because with elections can be formed "government of the people, by the people and for the people" (Faridhi, 2019), so that elections are indeed considered as the main and first benchmark of democracy, meaning that the implementation and results of elections are a reflection of the atmosphere of openness and application of the basic values of democracy And elections also have a big influence on a country's political system.

Election for the community as an opportunity to participate with the emergence of prospective leaders and screening of candidates who will contest, in line with the opinion of Harmaily Ibrahim in the Tutik Quarterly Point namely; Election is one of the basic rights of citizens, because in the implementation of human rights is a must for the government to carry out elections. In accordance with the principle that the people are sovereign then all of that is returned to the people to determine it (Tutik, 2011). In Indonesia itself as a country that adheres to the sovereignty of the people using elections as a tool to capture public officials such as legislative members and the president and his deputies at the same time, as mentioned in Article 6A Paragraph (1) of the 1945 Constitution of the Republic of Indonesia (after the amendment). As Jimly Asshiddiqie formulated the objectives of organizing the elections into 4 (four) parts, namely: first, to enable an orderly and peaceful transition of government leadership; secondly, to enable the replacement of officials who will represent the interests of the people in representative institutions; third, to implement the principle of popular sovereignty; and fourth, to implement the principle of the rights of citizens (Sukriono, 2013).

Elections before 2019 were held separately between legislative elections (Pileg) and executive elections (Pilpres), which showed the winner of the executive election was not directly proportional to the winner of the legislative elections, so that the executive did not get adequate support 
from the legislature. Through simultaneous elections carried out with the hope of giving birth to a long coalition and can simplify the party patterns needed by the presidential system. In 2019 Indonesia will hold simultaneous elections, including in this case Riau Province.

The design of simultaneous elections in most countries, as suggested by Jones and many other researchers in Latin America, states that the legislative and executive electoral system in a multiparty system must combine the simultaneous implementation time, the proportional system in legislative elections, and the plurality system in determining the winner of the presidential election (Solihah, 2018). In carrying out general elections simultaneously all citizens who meet the requirements according to Article 43 Paragraph (1) of Law Number 39 of 1999 concerning Human Rights, namely: "every citizen has the right to be elected and to vote in elections based on equality of rights through voting that is direct, public, free, confidential, honest and fair in accordance with statutory provisions".

The 1945 Constitution of the Republic of Indonesia (hereinafter abbreviated as the 1945 Constitution) has guaranteed human rights. The attachment of the Indonesian people to human rights issues can be seen from the regulation of basic rights contained in the constitution. The regulation not only includes legal and political rights, but also in the socio-economic and cultural fields (Nasution, 2017).

The implementation of the General Elections, according to Article 22E Paragraphs (1) and (5) of the 1945 Constitution, has determined that the General Elections shall be held directly, publicly, freely, confidentially, honestly and fairly every five years, and held by a national General Election Commission, permanent, and independent (Asshiddiqie, 2006). Meanwhile, to run a simultaneous election the consequences would require a lot of ballots and the time needed for voters in the voting booth to be more. The state guarantees the right to fair and equal treatment to participants in the General Elections, fair treatment is also given to all citizens in the form of fulfilling the right to vote for each individual government giving space to each polling station (TPS) with the most capacity 500 (five hundred) people as mentioned in Article 350 Paragraph (1) of Law Number 7 of 2017 concerning Elections, and the number of ballots in each polling station is the same as the number of voters listed in the Permanent Voter List (DPT) and Additional Voters Register (DPTb) plus 2\% (two percent) of the DPT as a reserve.

People who are not registered as permanent voters are given the opportunity to cast their votes by showing their original Resident Identity Card (KTP) as mentioned in Article 348 Paragraph (1) of Law Number 7 of 2017 concerning General Elections, namely: Voters who are entitled to vote At TPS includes: first, the owner of an electronic identity card registered on the permanent voter list at the relevant TPS; second, the owner of an electronic identity card registered on the additional voter list; third, the owner of an electronic identity card that is not registered on the permanent voter list and additional voter list; fourth, residents who have the right to vote.

When KTPs can be used to vote in regional/general elections, the Government only issues KTP-el that use citizens' identity recording technology, and provides a single National Identification Number (NIK) that cannot be falsified or duplicated (Febrina, Amanda, Nofriyanti, \& Yulfiyanti, 2020), and in the process of issuance becomes complex problems, so that the issuance of (old) blue ID cards is no longer issued, and only makes el-KTPs as valid identification (Faridhi, 2018), becoming a reference for any electronic KTP holders who are not registered as permanent voters and registered as additional voters and residents who have the right to vote will be able to give their voting rights with the provisions of Article 
349 Paragraphs (1a), (1b) and (1c) which read as follows:

a. Voting in the polling stations that are in the neighborhood pillars in accordance with the address listed on the electronic KTP.

b. Register in advance at the local KPPS.

c. Conducted 1 hour before voting at the local polling station is finished.

The large number of people who have the right to vote, both the owner of an electronic KTP registered as permanent voter, and the people who have the right to vote, but not registered will cause problems with the lack of ballots. This problem occurred in Siak Regency, how was the implementation of the use of the Right to Vote based on Law Number 7 of 2017 concerning Elections in Siak Regency?

\section{Method}

This study uses a type of sociological (empirical) legal research methods, namely the type of legal research conducted by examining primary data that become Siak Regency. The population associated with this study consists of; first, the Chairperson of the Siak Regency Election Commission (KPU); secondly, the Chairperson of the Siak Regency Election Oversight Body (Bawaslu); and third, Political Observer at Lancang Kuning University. Data collection techniques are done by interview, observation and literature study. The data obtained are described descriptively and deductively drawn conclusions.

\section{Result and Discussion}

The 2019 General Election was the first simultaneous election to juxtapose presidential and legislative elections based on the Constitutional Court ruling Number 14/PUU-XI/2013 which was read on January 23, 2014. The Constitutional Court was authorized by the 1945 Constitution to examine the law against the Law Basic Law. The mandate of this decision then gave birth to Law Number 7 of 2017 concerning General Elections as the legal basis for the implementation of the 2019 Elections. The Constitutional Court (hereinafter abbreviated as MK) holds that Simultaneous Elections will reduce time wastage and suppress conflicts or horizontal friction in the community during election periods, apart from that, through simultaneous elections citizens can exercise their right to vote intelligently and efficiently (Ardipandanto, 2020). In other words, the Simultaneous Election will make the democratic process in the election cleaner than certain interests, especially those involving lobbying or political negotiations carried out by political parties before determining the Presidential and Vice Presidential Spouses which are often based on momentary interests, not in the interests of the nation and state in general and in the long run.

Based on Article 1 Paragraph (1) of Law Number 7 of 2017 concerning Elections, that elections are a means of popular sovereignty to elect members of the People's Legislative Assembly, members of the Regional Representative Council, the President and Vice President, and to elect members of the Regional People's Representative Council, which implemented directly, publicly, freely, confidentially and fairly in the Unitary State of the Republic of Indonesia based on the Pancasila and the 1945 Constitution of the Republic of Indonesia, which is carried out every 5 (five) years simultaneously on holidays or days that are closed nationally, through several stages that began 20 (twenty) months before the vote.

Election stages begin with, first, program planning and budgeting as well as drafting regulations for the implementation of elections; second, updating voter data and preparing voter lists; third, registration and verification of election participants; fourth, determination of election participants; fifth, determination of the number of seats and determination of the electoral district; sixth, nominating the President and Vice President and members 
of the DPR, DPD, provincial DPRD, and Rrgency/city DPRD; seventh, the election campaign period; eighth, calm period; ninth, voting and counting of votes; tenth, determination of election results; and eleventh, the oath of promise of the President and Vice President and members of the DPR, DPD, provincial DPRD, and regency/city DPRD.

KPU as one of the institutions appointed by law as the organizer of the election, therefore, as the organizer who has the responsibility to carry out the following tasks: first, describe the program and implement the budget; second, carry out all stages of implementation in the district/city based on statutory provisions; third, coordinating and controlling the stages of implementation by PPK, PPS, and KPPS in their working area; fourth, submit the voter list to the Provincial KPU; fifth, updating voter data based on the latest election data by taking into account population data prepared and submitted by the Government and establishing it as a voter list; sixth, conducts and announces recapitulation of vote counting results of DPR members, DPD members, Presidential and Vice Presidential Elections, and members of the Provincial DPRD and members of the relevant regency/city DPRD based on the minutes of vote recapitulation results in PPK; seventh, make the minutes of vote count and certificate of vote count and must submit it to witnesses participating in the General Election, Regency/City Bawaslu, and Provincial KPU; eighth, announcing the elected candidates for Regency/City DPRD in accordance with the allocation of the number of seats in each electoral district in the relevant regency/city and making news of the event; ninth, immediately follow up on findings and reports submitted by the Regency/City Bawaslu; tenth, socializing the implementation of Elections and/or relating to the duties and authority of Regency/City KPU to the public; eleventh, evaluating and making reports at each stage of holding an election; and twelve, carrying out other tasks given by the KPU,
Provincial KPU, and/or statutory provisions.

Based on interviews with the Chairman of the KPU of Siak Regency, Ahmad Rizal, S.H that in the implementation of the simultaneous elections in 2019, Siak Regency was generally good. This can be seen from the high level of community participation in giving their voting rights to the polling stations that have been provided by the election organizers. The percentages in the 2019 simultaneous elections then exceeded the voter participation target set by the KPU, as targeted by the KPU at $77.5 \%$, while voter participation reached $88.93 \%$ or around 58,853 inhabitants of the total voters. The number of voters determined by the KPU in the 2019 simultaneous elections are:

Table 1. Voter List in Siak Regency in 2019 Election

\begin{tabular}{llc}
\hline \multicolumn{1}{c}{ Data of Voters } & & Amount \\
\hline DPT Voters (A-3 & Male & 33.808 \\
KPU Model) & Female & 32.367 \\
& Total & 66.175 \\
\hline DPTb Voters (A- & Male & 1.097 \\
4 KPU Model) & Female & 1.074 \\
& Total & 2.171 \\
\hline DPK Voters (A. & Male & 3.990 \\
DPK-KPU & Female & 3.801 \\
Model) & Total & 7.791 \\
\hline Total of & Male & 38.895 \\
A1+A2+A3 & Female & 37.242 \\
& Total & 76.137 \\
\hline Source: Siak Regency KPU 2019
\end{tabular}

Descriptions from the Chairperson of the Siak Regency KPU, that those who did not exercise their right to vote in the 2019 elections were $11.07 \%$ or around 17,629 voters. The logistics distribution process of the election carried out by the KPU secretariat to the destination area is based on the number of registered voters as permanent and additional voters, while for voters who use electronic KTP is $2 \%$ of the total permanent voters. according to the Siak Regency KPU, that the process of distributing and transporting voting 
equipment and other support equipment for election needs carried out by the Siak Regency KPU Secretariat from the Siak Regency KPU office to the destination area (PPK, PPS and KPPS) is in accordance with the number, type, time , address, procedure for receipt of election logistics goods based on a predetermined priority scale. The KPU of Siak Regency in distributing logistics has compiled the priority scale for the distribution of Election logistics goods based on distance of location, travel time, geographical conditions, level of difficulty of the terrain as well as the means of transportation used and the level of security/vulnerability of the destination area. The administration of 2019 Election logistics distribution carried out by the KPU of Siak Regency has ensured that the Election logistics goods can be received by all levels of the election organizing body in a timely, exact, exact type, and right target according to the rules.

The logistics fulfilled by KPU in 2019 in Siak Regency are as follows:

Table 2. 2019 Election Ballots in Siak Regency

\begin{tabular}{|c|c|c|c|c|}
\hline \multirow{2}{*}{$\begin{array}{l}\text { Voting } \\
\text { Letter } \\
\text { Type }\end{array}$} & \multirow[t]{2}{*}{ Need } & \multicolumn{2}{|c|}{ Sorting Results } & \multirow[t]{2}{*}{ Replacements } \\
\hline & & Sufficient & Broken & \\
\hline $\begin{array}{l}\text { President } \\
\text { and Vice }\end{array}$ & 278.598 & 278.433 & 165 & 165 \\
\hline $\begin{array}{c}\text { DPD } \\
\text { Election }\end{array}$ & 278.598 & 278.417 & 181 & 181 \\
\hline $\begin{array}{c}\text { DPR Riau } \\
1\end{array}$ & 278.598 & 278.474 & 124 & 124 \\
\hline $\begin{array}{c}\text { DPRD } \\
\text { Dapil Riau } \\
\text { Province } 6\end{array}$ & 279.598 & 279.472 & 126 & 126 \\
\hline $\begin{array}{l}\text { DPRD } \\
\text { Siak } \\
\text { Regency } \\
\text { Dapil 1 }\end{array}$ & 80.157 & 80.133 & 24 & 24 \\
\hline $\begin{array}{l}\text { DPRD } \\
\text { Siak } \\
\text { Regency } \\
\text { Dapil } 2\end{array}$ & 64.915 & 64.603 & 312 & 312 \\
\hline $\begin{array}{l}\text { DPRD } \\
\text { Siak } \\
\text { Regency } \\
\text { Dapil } 3\end{array}$ & 68.499 & 68.236 & 263 & 263 \\
\hline $\begin{array}{l}\text { DPRD } \\
\text { Siak } \\
\text { Regency } \\
\text { Dapil } 4\end{array}$ & 69.029 & 68.992 & 37 & 37 \\
\hline
\end{tabular}

\section{Source: Siak Regency KPU 2019}

Participation is an important element in empowerment, participation is not only in the form of "voting" in general elections/regional head elections carried out routinely, it even guarantees involvement in the process (Hernimawati, Asyar, Faridhi, \& Yandra, 2019). The implementation of the voting rights of citizens in Siak Regency in general can be said to be successful, proceeding peacefully, it can be seen from the increased participation of the community to give their voting rights to the polling stations prepared by the local KPPS, but it cannot be denied, there are still problems arising from simultaneous election procurement. Based on interviews with the Chairperson of the KPU of Siak Regency, that the high capacity and workload of the organizing officers, starting from the KPPS to the adhoc position above, resulted in the death of executing officers.

There were 2 (two) officers who died in the 2019 Election, had received compensation from the KPU of the Republic of Indonesia in cash, one of whom came from Tualang Subdistrict, on behalf of Lamhot Siringgoringgo from TPS 01 Kelurahan Pinang Sebatang, who died at the age of 41 years due to exhaustion . While one other person was the Secretary of the PPS who was recorded dead in Siak Regency on behalf of Navid from Kampung Penyengat Sungai Apit District.

According to the Chairperson of Siak Regency Bawaslu Moh, Royani, S.IP, there were problems in the Election in Siak Regency, the issue of distributing logistics, voting equipment and counting of votes must be received by the KPPS no later than 1 (one) day before the day and date of voting as intended in article 341 paragraph (6) of Law Number 7 of 2017, and for the commencement of logistic distribution, the KPU must coordinate with the Republic of Indonesia Police in particular Siak Resort Police so that the distribution can run smoothly and the logistic storage can be 
well maintained. Logistical handling such as ballots is still not quite right on target, because there are still many ballots that arrive at the KPPS to the destination that are not in accordance with the planned address, so the ballots between polling stations are exchanged and have the potential to lack ballots at the TPS.

The issue of updating voters' data becomes a separate issue, that in updating data, the election organizers work together starting from the lowest organizer, namely KPPS as an official of the household and neighborhood unit (RT/RW) that will provide data to the official above it, namely the PPS and then to the PPK , From PPK to Regency KPU, and Regency KPU to Provincial KPU, and Provincial KPU to KPU Republic of Indonesia. However, in the implementation of updating voters' data, it does not run smoothly with the hierarchy of updating the data itself, because the local people who want to be collected by officers are not in their homes/places, because it cannot be denied that the number of migrants or migrants from other regions is quite large. Although the community already has a domicile in Siak Regency, not a few who use national holidays or closed days are used for holidays to the village or out of town. Then many in the community whose deceased family members did not report their deaths to the relevant agencies so that the data were still considered alive and were still registered as potential voters in the next election.

The election which was held on April 17,2019 was the first election in the history of the Republic of Indonesia held simultaneously between the Election of President and Vice President with the legislative election and carried out at the same time, the voting which started from 07:00 to 13:00 and continued with the ballot counting done. It is undeniable that the weight and marathon time to complete the voting process is to be completed.

The view of political observers conveyed by Alexsander Yandra, M.Si., that the simultaneous election held in 2019 still leaves many weaknesses, one of which is regarding the infrastructure of the election, preparation of the election implementation, and the immature electoral system. As for the background to the obstacles of holding simultaneous elections in 2019 is as stated by the Chairperson of the KPU of Siak Regency as follows: first, the low awareness of the community to take care of data transfer if the community changes address, for example the community has moved from the RT listed on the KTP to the RT other; secondly, when officers conduct a census to update voter data, many residents are not at home, this is because the homeowner sometimes returns home or goes out of town; Third, voters registered as voters who die are very rare, even their heirs have never taken care of death certificates to related agencies, so that the population data remains alive which results in voter data in the next election reappearing.

\section{Conclusion}

The implementation of voting rights of citizens in the 2019 simultaneous elections in Siak Regency has not been implemented properly, there are problems faced by the organizers of the general election both from the Siak Regency KPU and from the PPS to the KPPS as implementing at the TPS in Siak Regency, there are problems with the lack of ballots in polling stations that make election organizers have to spend extra energy to fulfill the voting rights of voting rights holders, the lack of public knowledge of their voting rights and determination, as well as the issuance of DPT that has not been good so that in the voting implementation many people who have the right to vote cannot give their voting rights because it is not registered as a DPT, the people only use electronic KTPs to cast their ballots, lack of or lack of time in coordinating between the polling station officials at the polling station or voting. 


\section{References}

Ardipandanto, A. (2019). Problems of Organizing Simultaneous Elections in 2019. Jurnal Info Singkat, 11(11), 2530.

Ardipandanto, A. (2020). Dampak Politik Identitas Pada Pilpres 2019: Perspektif Populisme [The Impact of Identity Politics On President Election 2019: Populism Perspective]. Jurnal Politica Dinamika Masalah Politik Dalam Negeri dan Hubungan Internasional, 11(1), 43-63.

Asshiddiqie, J. (2006). Introduction to State Administration Law $2^{\text {nd }}$ Edition. Jakarta: Konstitusi Press.

Faridhi, A. (2014). Polemic of Campaign Materials in the Election of Pelalawan District 2015. Riau Law Journal, 1(2), 124-143.

Faridhi, A. (2017). Testers of the Single Legitimate Regulations. Mercatoria, 10(2), 180-196.

Faridhi, A. (2018). Penggunaan Surat Keterangan Dalam Pemilihan Kepala Daerah Kota Pekanbaru Tahun 2017. Jurnal Ilmiah Penegakan Hukum, 5(2), 86-93.

Faridhi, A. (2019). Sengketa Pencalonan Pemilihan Kepala Daerah Kota Pekanbaru Tahun 2017. Pagaruyuang Law Journal, 2(2), 239-256.

Febrina, R., Amanda, F., Nofriyanti, J., \& Yulfiyanti Hutabarat, J. (2020). Capability of Updating the List of Permanent Voters by Pekanbaru Election Commission During 2019 Election. Journal of Election and Leadership, 1(1), 1-6. https://doi.org/10.31849/joels.v1i1.343 6

Hernimawati, H., Asyar, Y., Faridhi, A., \& Yandra, A. (2019). Prinsip-Prinsip Berdemokrasi Bagi Penyandang
Disabilitas Tuna Grahita Pada Pemilihan Umum 2019 Di Provinsi Riau. Nakhoda: Jurnal Ilmu Pemerintahan, 18(1), 11-20.

Hernimawati, H., Asyar, Y., Faridhi, A., \& Yandra, A. (2019). Principles of Democracy for Persons with Disabilities in the 2019 General Election in Riau Province. Helmsman: Journal of Government Science, 18 (1), 11-20.

Nasution, B. J. (2017). State of Law and Human Rights. Bandung: CV. Mandar Maju.

Putusan Mahkamah Konstitusi Nomor 14/PUU-XI/2013.

Solihah, R. (2018). Peluang dan tantangan pemilu serentak 2019 dalam perspektif politik. JIIP: Jurnal Ilmiah Ilmu Pemerintahan, 3(1), 73-88.

Solihah, R. Opportunities and Challenges of 2019 Concurrent Elections in Political Perspectives. Scientific Journal of Government Science, 3(1), 73-88.

Sukriono, D. (2013). Constitution Law and Autonomy Concept. Malang: Setara Press.

Sukriono, D. (2013). Hukum, konstitusi, dan konsep otonomi: kajian politik hukum tentang konstitusi, otonomi daerah dan desa pasca perubahan konstitusi. Setara Press.

Tutik, T. T. (2011). Undang-Undang Dasar Negara Republik Indonesia tentang Undang-Undang Dasar Perubahan.The Constitutional Law of Indonesian Constitutional Law Post Amendment. Jakarta: Kencana.

Undang-Undang Dasar Negara Republik Indonesia Tahun 1945.

Undang-Undang Nomor 39 Tahun 1999 tentang Hak Asasi Manusia.

Undang-Undang Nomor 7 Tahun 2017 tentang Pemilihan Umum. 